\title{
Slaves to the Bottle: Smith's Civil Damage Liquor Law
}

\author{
ELAINE FRANTZ PARSONS
}

This brief summary of the humble lives of the plaintiff and her husband the two principal characters in this tragical case may be pardoned. . . . [Michael Judge] was 28 years old, a strong, able bodied, healthy, hard working, laboring man. Nine years before while yet a boy he married Mary, a very queen among women as the most cursory perusal of the evidence will show; up to this fatal Sunday afternoon they had lived in Lyons continuously for seven years.... he was the sole support of his darling wife, and his Mary was spotless in the crowning glory of woman, he was honest and industrious and they were happy. $\mathrm{He}$ is no longer a laborer, he walks the streets of Lyons today on one leg and his true hearted wife Mary J. Judge the plaintiff in this case bends over a washtub day after day to keep them from starving. ... Who and what contributed in the largest measure to the breaking up of this happy little home? Whiskey, the demon of man was the weapon and it was deliberately wielded by [the saloonkeeper].'

Research for this article was made possible by grants from the State Historical Society of Iowa and the Littleton-Griswald Research Fund of the American Historical Association, and by the hospitality of Susan Cramer, Carolyn Frantz, Evelyn Holler, Judy and Ed Pilewski, and Peggy, Mark, Eric, Allyn, Tim, Emily, Anna, Kristin, and Rebeckah Weddle, and by the excellent staff of the Iowa State Law Library, especially Linda Robertson, Carol Emerson, and Timothy Gatti; of the State Historical Society of Iowa Libraries in Des Moines and Iowa City; and of Nancy Witman at the Michigan Law Library; M. Cody Wright, James Cohlmeyer, and Charles Cali at the Illinois State Archives; and Jill Trueblood at the Illinois Supreme Court. I would like to thank Marvin Bergman for his encouragement, and the Annals's anonymous readers for pointing out valuable primary sources I had overlooked.

1. Mary J. Judge v. John Jordan and Patrick O'Connor (1889), Appellee's Argument, p. 1, Bound Briefs, Iowa State Law Library (hereafter cited as ISLL), Des Moines

THE ANNALS OF IOWA 59 (Fall 2000). (C) The State Historical Society of Iowa, 2000. 
ON SUNDAY AFTERNOON, January 2, 1887, 28-year-old day laborer Michael Judge went to his favorite saloon in Lyons, Iowa. We cannot be sure exactly how much he drank there. He certainly was in no condition to remember. If anyone knew, it was probably the saloonkeeper, John Jordan, and he had good legal reasons not to tell. However much Judge drank, when he left the saloon for home that cold winter evening, he collapsed on the street. A building in town caught fire during the night, and in the midst of the resulting chaos one of the firefighters, W. W. Buell, noticed Judge lying on the street and tried to help him to shelter. When Judge resisted, however, Buell gave up and went back to firefighting, leaving Judge to remain on the street for many hours. By the time Judge was finally taken off the street by another passerby, he had developed such severe frostbite that one of his legs had to be amputated. Two years later, Michael's wife, Mary, filed a suit against John Jordan and his business partner, asking for $\$ 15,000$ for the cost of Michael's medical care and for his lost earning potential. The jury ultimately awarded her $\$ 1,500$, which was still a lot of money at a time when a day laborer earned two or three dollars a day. ${ }^{2}$

Mary Judge was able to seek compensation from Jordan because of a piece of Iowa legislation called Smith's Civil Damage Liquor Law. That law, passed in 1862, allowed drinkers' dependents to sue alcohol vendors. The law was based on a highly

(74 Iowa 166, 37 N.W. 131). This paper is based largely on an exciting and previously neglected set of sources: trial transcripts from nineteenth-century court cases. These are valuable sources because they contain often lengthy transcriptions of the words of many non-elite Iowans who otherwise left no written record of their thoughts and experiences. Thousands of such transcripts remain in Iowa. Most are not easily accessible, because they are scattered throughout the state in district courthouses. Those from cases that were ultimately heard by the state supreme court, however, have been printed, bound, and deposited at the Iowa State Law Library, Drake University, and the University of Iowa. I used the set of bound briefs housed at the Iowa State Law Library, and my citations refer to that collection. For readers who may be interested in seeing the resolution of the cases, my footnotes also include citations to the Iowa Supreme Court decision in each case. (These standard legal citations are also required to locate the particular brief in the collection of bound briefs housed at the University of Iowa.) These decisions do not include the transcripts, so the reader who wants to find the context of the quotations included in this article will need to consult the bound briefs.

2. Judge v. Jordan, Plaintiff's Petition, p. 2; Verdict, p. 63. 
unusual idea about the nature of individual responsibility - the notion that the state could hold one individual liable for the consequences of the actions of another. Although that notion seemed strange to many at the time, Smith's Law did have some precedents: both Massachusetts and Pennsylvania had passed similar laws in the 1840s; Kansas and Ohio had passed weak forms of it in the 1850s; and some southern judges had made similar rulings in the 1840 s and 1850 s in cases involving drinking by slaves.

When Iowa's legislators passed Smith's Law in 1862, however, the legal notion it represented was still both novel and controversial. The law made it possible for any individual who had been injured by another person's drinking to sue the saloonkeeper who had sold that person alcohol. Specifically, under this law, "every wife, child, parent, guardian, employer or other person who shall be injured in person or property, or means of support, by any intoxicated person, or in consequence of the intoxication, habitual or otherwise, of any person .... shall have a right of action ... against any person or persons who shall by selling intoxicating liquors as in this Act set forth, cause the intoxication of such person."

Smith's Law did not take drinkers "off the hook"; courts generally still held drinkers criminally and civilly responsible for their acts while intoxicated. Rather, it imposed a redundant responsibility, both on the drinker and on the drink purveyor. Plaintiffs "injured in person or property" who were not dependents of drinkers could choose whether to sue drinkers or

3. Ernest H. Cherrington et al., eds., Standard Encyclopedia of the Alcohol Problem, 6 vols. (Westerville, OH, 1924-1930), cited in Jack S. Blocker, Give to the Winds thy Fears: The Women's Temperance Crusade, 1873-1874 (Westport, CT, 1985), 125; Skinner v. Hughes (1850), 13 Mo. 440, as reported in 97 A.L.R. 3d 528, 557; and Harrison v. Berkeley (1847), 32 S.C.L. 525, as reported in 97 A.L.R. 3d 528, 557.

4. 1862 Laws of Iowa, 50. In keeping with the language of this law, which specifies that wives and children have the right to sue, but does not specifically mention husbands, I deliberately use masculine pronouns throughout this article to describe "the drunkard." While there certainly were plenty of women who drank excessively in nineteenth-century Iowa, the image of the drinker or drunkard in nineteenth-century minds was decidedly male. In fact, female drinkers in the nineteenth century were often thought of as masculine. When Iowa's legislators and reformers considered the social cost of drinking, they had male drinkers in mind. 
saloonkeepers, though saloonkeepers, who often had "deeper pockets," were frequently more appealing targets. Today, civil damage laws are used primarily by people who have been hit by drunken drivers. When such laws were first passed, however, they were primarily intended for and used by people such as Mary Judge - the wives and children of men who were killed or maimed while intoxicated, or who simply drank too much to be good providers. ${ }^{5}$

Dramshop laws were, and still are, the cause of great confusion and annoyance to many legal scholars who argue that they are jarringly out of accord with the rest of the legal tradition. ${ }^{6}$ An authoritative work on the law of intoxicating liquors published in 1910 complained that "much confusion has resulted from the loose way in which the term 'proximate cause' has been used by courts and writers" in civil damage cases. ${ }^{7}$ Somehow, in the middle of the nineteenth century, a handful of state legislatures, including Iowa's, passed a type of law that appeared to be based on a different notion of legal responsibility than the rest of American law.

Iowa's role in the history of civil damage laws was crucial largely because of its timing and context. First, it was early. Iowa was the first midwestern state to pass a strong version of the act. Over the course of the next two decades, most neighboring states would follow its lead. Second, the Iowa legislature was the only one to pass its act during the Civil War. The idea of "slavery" was central both to the war and, as we will see, to the logic of the civil damage acts. Iowa's decision to pass it in 1862 made that relationship clear.

Smith's Law has had profound and enduring consequences. A number of states would follow Iowa's lead over the next twenty years. Such laws remain on the books and in use today in many states, including Iowa. They, in turn, have served as

\footnotetext{
5. Although children had the right to recover under the Act, they could not themselves be plaintiffs. Rather, adults (often their mothers) brought suits on their behalf.

6. See Timothy Lytton, "Responsibility for Human Suffering: Awareness, Participation, and the Frontiers of Tort Law," Cornell Law Review 78 (1993), 492-95. 7. W. W. Woollen and W. W. Thornton, Intoxicating Liquors: The Law Relating to the Traffic in Intoxicating Liquors and Drunkenness (Cincinnati, $\mathrm{OH}, 1910), 1864$.
} 
precedents for other important twentieth-century litigation and legislation. The sweeping consequences of Smith's Law were not limited to the legal sphere. Its passage affected the lives of thousands of Iowa drinkers, drinkers' families, and saloonkeepers. It changed the way saloonkeepers did business, the way drinkers experienced their leisure time, and the way wives and children interacted with their saloon-going providers.

The Iowa legislature passed the law during an exceptional historical period and under the influence of a new and radical body of ideas. In passing the bill, Iowa's legislators wrote into law and thereby perpetuated a new constellation of popular ideas about moral and legal responsibility. The story of the bill's history, then, is the story of how legislators and other nineteenthcentury midwesterners came to reimagine responsibility and autonomy. The most interesting part of the story may well be the lessons it teaches about how new complexes of ideas spread: how they come to be transmitted from one region to another and from one subject to another. To explore the history of Smith's Civil Damage Liquor Law is to trace the process by which an idea, emerging at the right historical moment, became a permanent part of the law, and in turn changed not only the shape of the law itself, but the experiences of those living under it. ${ }^{8}$

IT IS NOT EASY for litigious Americans at the turn of the twenty-first century to recognize just how radical and unusual Smith's Civil Damage Liquor Law was. Before its passage, Mary Judge would have had no claim against John Jordan. Under the

8. In the past few years, some scholarly attention has focused on the history of liquor legislation in the United States. The two standard recent monographs on the subject are Richard F. Hamm, Shaping the Eighteenth Amendment: Temperance Reform, Legal Culture, and the Polity, 1880-1920 (Chapel Hill, NC, 1995); and Perry R. Duis, The Saloon: Public Drinking in Chicago and Boston, 1880-1920 (Urbana, IL, 1983), which usefully compares saloon regulation in Boston and Chicago. To learn about the progress of temperance legislation in one of Iowa's neighboring states, see Robert Smith Bader, Prohibition in Kansas: A History (Lawrence, KS, 1986). The most thorough treatment of the history of liquor legislation in Iowa is Dan Elbert Clark, "The Beginnings of Liquor Legislation in Iowa," Iowa Journal of History and Politics 5 (1907), 193-212; idem, "The History of Liquor Legislation in Iowa," ibid. 6 (1908), 55-87, 339-74, 503-608. For a broader view of the legislative context out of which liquor legislation emerged, see John E. Briggs, History of Social Legislation in Iowa (Iowa City, 1915). 
common law, drinkers' dependents did not have the right to recover damages from saloonkeepers. ${ }^{9}$ Traditionally, an injured person only had the right to sue someone if that person's action had directly caused the injury. If some other person's action had intervened between the first person's action and the injury, the first person would not be held responsible. If John Smith failed to secure his horse adequately to a post, and then Robert Jones began deliberately tormenting the horse so that it bolted down the street, harming Mary Brown, Brown could recover from Jones, but not Smith. So, under the common law, when Michael Judge got drunk and lost his leg to frostbite, John Jordan might have played an important role in the injury, but Judge himself, by voluntarily drinking the alcohol, bore ultimate legal responsibility for having become intoxicated. His own act of drinking, then, was the "proximate cause" of his injury, and of his wife's loss of income. Since the act of the drinker in consuming an alcoholic beverage superceded the act of the saloonkeeper in selling the beverage as a cause of intoxication, even if intoxication had "caused" an injury, the saloonkeeper was not legally responsible. ${ }^{10}$

Civil damage laws such as Smith's changed this. They "displaced the common-law rule that the proximate cause of intoxication was not the furnishing of the liquor but its consumption. ${ }^{11}$ Although Smith's Civil Damage Liquor Law was quite unusual at the time, it has come to sound more familiar in recent years as individuals and governments have brought con-

9. For a summary of the history of the legal reasoning behind civil damage laws in the nineteenth century, see the extensive and well-documented historical digression in the Connecticut Supreme Court's decision in the case of Nolan v. Morelli (1967), 154 Conn. 432, 226 A.2d 383.

10. See, for instance, the discussion King v. Henkie (1886) $80 \mathrm{Ala} 505$, as reported in 54 A.L.R. 2d 1156: "whatever wrong or negligence might be attributable to the defendant was not an approximate or efficient cause of death, because the defendant merely sold the liquor, and that in and of itself would not have produced the fatal result had not the decedent of his own volition, or as a result of his voluntarily having destroyed his senses, drunk the liquor." See also 97 A.L.R. 3d 533: "At common law, it was not a tort to either sell or give intoxicating liquor to ordinary able-bodied men, and no cause of action existed against one furnishing liquor in favor of those injured by the intoxication of the person so furnished, the reason usually given for this rule being that the drinking of the liquor, not the furnishing of it, was the proximate cause of the injury."

11. Nolan v. Morelli, 154 Conn. at 437. 
troversial lawsuits against cigarette manufacturers. There is nothing particularly novel about basing a suit on the argument that using tobacco products has damaged smokers' health. Manufacturers have long faced lawsuits when their products have malfunctioned or posed hidden dangers. Nor is it strange for plaintiffs to seek additional damages by arguing that tobacco companies withheld and manipulated the evidence they had about their products' dangerous effects while continuing to sell a product they knew to be harmful. Plaintiffs in cigarette cases face a special challenge, however, since the health risks of smoking were well known even though cigarette makers denied them. Because most smokers had been amply warned of the health risks of tobacco products, it is more difficult to maintain that cigarette companies' manipulations and cover-ups did much to change smokers' behavior and that the smokers themselves did not voluntarily contribute to their own injury. Largely as a response to this challenge, plaintiffs have mobilized another argument to place responsibility for the consequence of cigarette use on tobacco companies. They have maintained that the tobacco companies deliberately caused smokers to become addicted to their product. Even though tobacco products have long carried governmental warning labels about their health effects, and even though those health risks were well known to smokers, they were unable to stop using them because tobacco companies, by clever and deliberate manipulation of nicotine levels and so on, worked hard to keep them dependent.

Civil damage legislation such as Smith's Civil Damage Liquor Law laid the groundwork for this sort of legal reasoning. In the nineteenth century thousands of women like Mary Judge, and also drinkers' children represented by their "next friends" (usually their mothers), brought suits against saloonkeepers for compensation for damages caused by their husbands' and fathers' alcohol use. Like cigarette suits today, nineteenth-century suits against the saloon appealed to legislators and others partly for economic reasons. Nineteenth-century saloon-going, like smoking today, carried a heavy social cost. Today's taxpayers have to foot the bill for many patients with diseases such as emphysema and lung cancer. Similarly, nineteenth-century citizens had to provide some level of support for the families of 
those "drunkards" who were injured, killed, or rendered incompetent as breadwinners as a result of drink. It made sense to nineteenth-century legislators to require those who profited from the sale of alcohol to compensate families who were harmed by the breadwinners' use of their product. Not only would that ease the burden on the rest of the community, it would make saloonkeeping a less attractive line of business to go into, and would force those who persisted in keeping saloons to look after the welfare of their customers.

But economic considerations were only part of the motivation. Holding saloonkeepers responsible for the consequences of their customers' drinking also made sense to many nineteenthcentury Americans because they believed that, as cigarette plaintiffs argue of cigarette manufacturers today, saloonkeepers deliberately addicted their customers to alcohol, and that drinkers therefore were not free to stop using it before it injured them and their families. Because of more general changes in ways of talking about alcohol and free will, the belief that saloonkeepers could be held responsible for the consequences of their customers' behavior had become plausible by the mid-nineteenth century in a way it never had been earlier.

Many historians have written about the cultural importance of the saloon in the nineteenth century. In both urban and rural communities, it served as a central space where men came together socially. It was the place to go to get the local news, to find temporary work or workers, to make business deals, to get out of bad weather, to grab a bite to eat, and, of course, to have a few-or more than a few-drinks. ${ }^{12}$

By the 1850 s, as Iowa became more heavily settled, an increasing number of Iowans were complaining that saloons were

12. Although most of the work on the saloon culture has focused on cities and on the Northeast, it is still useful for the historian of the midwestern saloon. See, for instance, Duis, The Saloon; Catherine Gilbert Murdock, Domesticating Drink: Women, Men, and Alcohol in America, 1870-1940 (Baltimore, 1998); Thomas J. Noel, The City and the Saloon: Denver, 1858-1916 (Lincoln, NE, 1982); Madelon Powers, Faces Along the Bar: Lore and Order in the Workingman's Saloon, 1870-1920 (Chicago, 1998); and Roy Rosenzweig, Eight Hours for What We Will: Workers and Leisure in an Industrial City, 1870-1920 (New York, 1983). For a wonderful older anecdotal account of saloon life, see George Ade, The OldTime Saloon: Not Wet - Not Dry Just History (New York, 1931). 


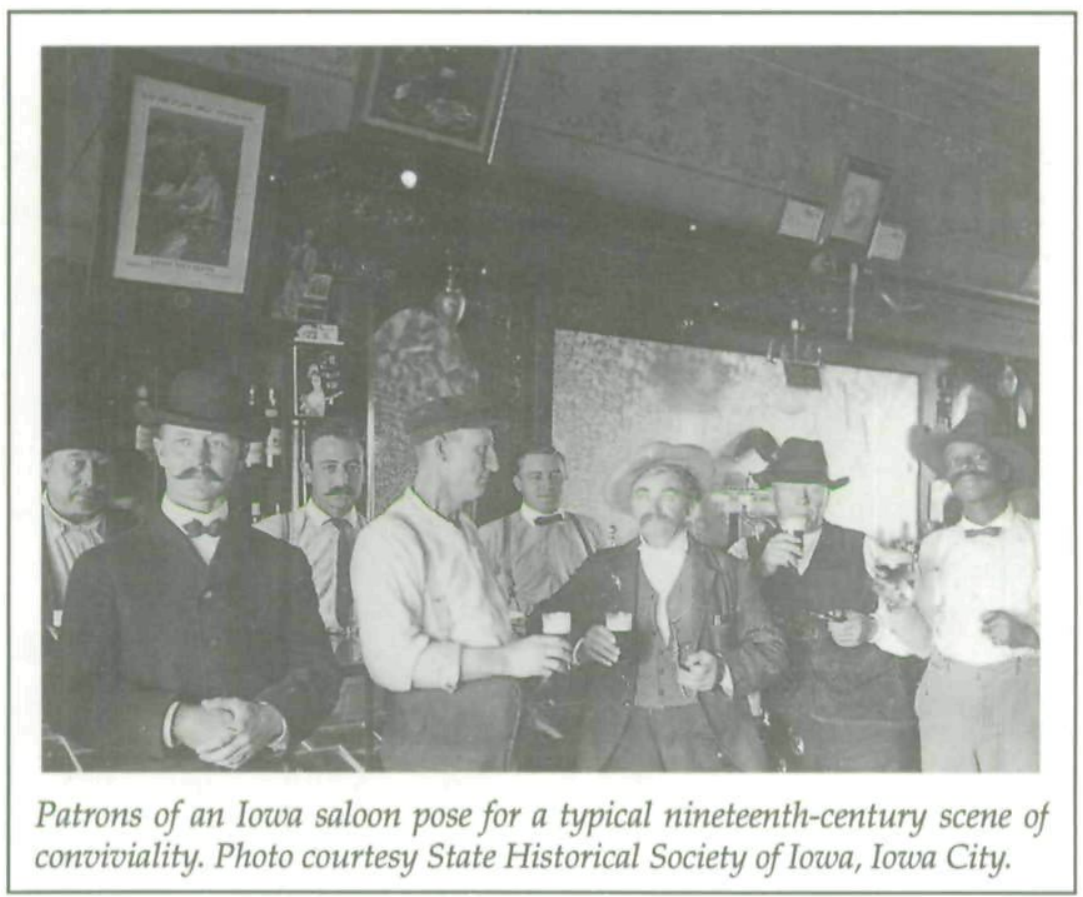

a social problem. They argued that too many formerly upstanding men were becoming drunkards who were unable to support their families, who threatened the peace and safety of their communities, and who were incapable of being good workers and citizens.

Citizens dealt with the recognition that the consumption of alcohol was a social problem in two ways. First, they disciplined those drinkers who were burdening their families and communities, punishing them for vagrancy and public drunkenness. But they also struck out in a new direction, blaming the saloon, and the saloonkeeper, for causing alcohol-related social problems. In 1853, for instance, the Keokuk Sunbeam reported, "We learn of a case in eastern New York where a rumseller has been held to bail in the sum of $\$ 1000$, on the charge of manslaughter, for selling liquor to a drunkard, after the remonstrance of his friends. Just as it should be. ${ }^{\prime 13}$ The sentiment this

13. Keokuk Sunbeam, 1 June 1853. 
article expressed was consistent with a general trend toward assigning blame to the seller of the drink along with or rather than the drinker himself. Those most concerned about the alcohol problem were coming to believe that the best way to address it was not to punish or condemn drinkers, but rather to attack saloons and saloonkeepers.

IT IS USEFUL to think about the temperance movement generally, and the civil damage acts in particular, geographically. Temperance reform had a long history by the time of the Civil War. Attacks on alcohol, which would eventually result in national prohibition, had begun in earnest in New England and the mid-Atlantic in the 1820s through the 1840s. The East Coast was clearly dominant in the movement during its early years. The first major temperance organizations were headquartered in the East. The American Temperance Society, for instance, began in 1826 in Massachusetts. The Washingtonians, who dominated the temperance scene in the 1840s, started out in Baltimore. The Sons of Temperance, important in the 1850s, began in New York. ${ }^{14}$ Around the time of the Civil War, however, two things happened to the movement. First, it lost momentum as reformers shifted their energy and attention to the war effort. Second, its center shifted from the East Coast to the upper Midwest, where it would remain through the rest of the century. After the war, the two biggest temperance groups were of midwestern origin. The Woman's Christian Temperance Union began in Ohio and was headquartered in Illinois. The Anti-Saloon League also emerged from Ohio. ${ }^{15}$ Iowa, with both a strong body of prohibition supporters and a significant pro-saloon contingent, became a crucial and hotly contested battleground in the movement.

Smith's Civil Damage Liquor Law was Iowa's first major effort to hold saloonkeepers legally responsible for their clients'

14. For a brief survey of early temperance movements, their eastern origins, and their spread to the West, see Jed Dannenbaum, Drink and Disorder: Temperance Reform in Cincinnati from the Washingtonian Revival to the WCTU (Urbana, IL, 1984), 16-62.

15. Dannenbaum, Drink and Disorder, 227. On the origins of the Anti-Saloon League, see K. Austin Kerr, Organized for Prohibition: A New History of the AntiSaloon League (New Haven, CT, 1985). 
behavior. Although it was patterned after similar laws that had already been passed in Massachusetts and Pennsylvania, ${ }^{16}$ the history of liquor legislation in Iowa during its territorial and early statehood periods established the Hawkeye State as one of the leaders in this area. Iowa was settled and organized during the period when northern reform sentiment was at its height, and temperance was one of the major reforms of the era. Many looked at Iowa as a blank slate, providing the opportunity to structure a community that would be free of the social vices plaguing eastern cities. Even before Iowa gained statehood, its leadership had been both public and aggressive in condemning alcohol use. Robert Lucas, the first governor of the Iowa Territory, in his first address to the territorial legislature in 1838, identified intemperance, along with gambling, as "the fountains from which almost every other crime proceeds." The very next year, Lucas would agree to serve as president of a territorial temperance society. His was also among the earliest voices calling for local option legislation, that is, legislation giving each town the right to ban liquor within its limits. This local option legislation finally passed a decade later, in 1847, though it was very poorly enforced and soon repealed. ${ }^{17}$

Lucas, after leaving office, continued his temperance work. In 1850 a newspaper in distant Tennessee reported an exciting new idea for temperance legislation proposed at a temperance convention by Lucas and other prominent Iowa reformers. Under that legislation, "Persons furnishing liquors [would be considered] particeps criminis if any crime be committed in consequence of it. ... Sellers [would be held] liable also for damages that ensue [in consequence of drinking their liquors]. ${ }^{\prime 18}$ Although similar laws had been passed in Massachusetts and Pennsylvania,

\section{Davemport Daily Democrat and News, 17 March 1862.}

17. "Governor's Address," Journal of the House of Representatives of the First Legislative Assembly of the Territory of Iowa (Burlington, 1838), 8; Clark, "The Beginnings of Liquor Legislation," 201; idem, "The History of Liquor Legislation," 56. For more on Lucas, see Robert R. Dykstra, Bright Radical Star: Black Freedom and White Supremacy on the Hawkeye Frontier (Cambridge, MA, 1993), 23.

18. Brownlow's Knoxville Whig, 30 November 1850. Other leaders of the convention were Joseph Williams, Chief Justice of the Supreme Court (president); Dr. Parke (vice-president), and L[incoln?] Clark. 
they had received little press and seem to have been little used, so the Iowa convention's proposed legislation received national attention as a novel solution. It also laid the groundwork in Iowa for Smith's Civil Damage Liquor Law, which would be passed a dozen years later.

Iowa was a fertile field in which transplanted eastern reformist notions and experiments such as civil damage laws could flourish. But Iowa also had a different relationship to the "liquor problem" than did its eastern neighbors; its frontier location may have made the controversial civil damage laws even more appealing to it. During the territorial and early statehood periods, Iowans associated the evils of alcohol with "the Indian problem." They were convinced that the alcohol being provided to American Indians by white traders led to the tribes' decline. Governor John Chambers, in his 1845 message to the legislature, piously expressed a fear that, "so long as [the Winnebagoes] are supplied with liquor ... they will continue to diminish in number and to descend if possible, into still lower depths of degradation. ${ }^{\prime 19}$ Iowans were almost certainly more concerned about American Indian drinking, however, because they believed that it inspired violence against white settlers. Legislatures in those early years, therefore, spent a good deal of time and energy trying to prevent the sale of alcohol to American Indians.

In moving to frontier Iowa, then, northeastern reform notions such as temperance encountered new influences and took on new significance. As legislators addressed the issue of drinking by whites and Indians alike, it would be surprising if the two separate issues had not informed and shaped one another. Iowans' focus on the devastating impact of alcohol on American Indian tribes increased their concerns about the danger that white drinkers posed to their own families and communities. ${ }^{20}$ More importantly still, Iowa legislators agreed that Indian drinking problems were best addressed not by attempting to reform

19. "Governor's Message," Journal of the House of Representatives of the Seventh Legislative Assembly of the Territory of Iowa (Fort Madison, 1845), 17.

20. For a detailed account of the relationship between tribal decline and prohibition sentiment in nineteenth-century temperance discourse, see Elaine Frantz Parsons, "Manhood Lost: Drink, Gender, and the Self in the NineteenthCentury United States" (Ph.D. diss., Johns Hopkins University, 1999), 188-92. 
the Indians themselves, but rather by penalizing those who provided the liquor. When Governor Lucas, who was leading the charge against liquor sales to Indians, said that liquor sellers were "morally accountable for all the crimes and wretchedness produced by the use of such ardent spirits," he might as well have been referring to Indian traders. In fact, however, he was talking about those who sold liquor to white Iowans. ${ }^{21}$

As Iowans grew increasingly concerned about the consequences of the liquor trade, they perpetually deluged the territorial and early state legislatures with petitions calling for either a tightening or a loosening of liquor legislation. As a result, the legislatures considered some form of temperance legislation in every session. Liquor laws frequently emerged as partisan issues in Iowa as they did on the national stage. The state regularly flip-flopped between local option, license, prohibition, and anti-saloon legislation. In 1846, for instance, legislators passed a local option law. ${ }^{22}$ The next year, they gave voters the right to vote to exclude the sale of liquor in amounts of less than one gallon in their counties. They believed that this law would not survive a legal test, however, and did not enforce it, though it stayed on the books. In 1851, when a court upheld a similar law in Pennsylvania, Iowa legislators determined that their law was, in fact, constitutional. ${ }^{23}$ Often, they would pass strong-sounding anti-liquor laws, but would add amendments that rendered them insignificant. In 1855, for example, they amended a prohibitory law to exclude apple cider and grape, currant, and other wines produced in the state. ${ }^{24}$

Smith's Civil Damage Liquor Law was a breath of fresh air in this longstanding political morass. Like most anti-alcohol legislation, the bill drew its support from Republicans and was opposed by most Democrats. Named after Senator Sherman G. Smith, a 29-year-old Republican lawyer from Jasper, the bill inspired considerable partisan debate. With a significant Republican majority in both houses, however, the bill passed handily.

21. Clark, "The Beginnings of Liquor Legislation," 201.

22. 1846 Iowa Territorial House Journal, 12 January 1846, HR File No. 29.

23. 1850 Iowa House Journal, 195-96.

24. 1855 Iowa House Journal, 213. 
IT WAS NO COINCIDENCE that Iowa's attack on the saloon should have come during the Civil War. The war had both fed on and generated strong antislavery sentiment in the North, so it made rhetorical sense for Iowa Republicans to concern themselves with "slaves to the bottle" as they warred against the southern slave power. Antebellum reformers, as early as the 1840s, had argued that drinking was a form of slavery, and had spread that view not only in speeches and newspapers, but also in songs, poems, short stories, and novels about the plight of the drinker and his family. ${ }^{25}$ These reformers described drinkers as fettered to the bottle, to the "rum power" (something similar to the "slave power" that Free Soilers found so threatening), or to their own corrupt desires. Iowans both within and outside the legislature were familiar with and generally sympathetic to this parallel between African American slaves and slaves to the bottle. In other words, many Iowans saw drinkers-particularly heavy drinkers-as slaves to the saloonkeeper, who had control over their money, their time, and their actions. Like southern slaves, Iowans believed, heavy drinkers lacked the freedom to make their own choices about how to live their lives.

Just because some Iowans saw drinking as a form of slavery does not necessarily mean that they assumed drinkers lacked legal responsibility for their own actions. Indeed, the question of the extent to which others could be held legally responsible for the consequences of the actions of actual slaves posed a serious dilemma for antebellum southern courts. As it turns out, the peculiar idea of moral responsibility manifested in the civil damage acts may well have derived from the way the Peculiar Institution itself handled this question.

Historian Mark Tushnet, in his study of the law of slavery in the antebellum South, argues that there was a fundamental contradiction in American slave law between the desire to base

25. See, for instance, A. D. Milne, Uncle Sam's Farm Fence (New York, 1854). Harriet Beecher Stowe, author of Uncle Tom's Cabin, also used the term slave to describe heavy drinkers. See Harriet Beecher Stowe, "Betty's Bright Idea," in Betty's Bright Idea. Also, Deacon Pitkin's Farm, and The First Christmas of New England (1876; reprint, Freeport, NY, 1972). 
decisions on humanity or on interest. ${ }^{26}$ To what extent should slaves be considered as subjects, in which case the law had a responsibility to protect them and enforce their rights? To what extent should they be considered chiefly as property, in which case the law's primary responsibility in relation to slaves was to enforce their masters' rights to their persons and labor? This question of whether slaves should be considered as subjects or objects ultimately reduced to whether they should be considered as humans possessing free will or as objects merely serving the will of masters. To preserve the embattled slave society, it was necessary that the law protect masters' proprietary rights to slaves, but slaves kept on behaving unmistakably as though they possessed wills of their own. Southern lawmakers' and judges' attempts to deal with slaves, who were at once humans and property, who sometimes acted as extensions of their masters' will and sometimes willed their own actions, exacerbated a significant awkwardness in the legal system. It introduced a large class of sane adults whose responsibility for their own actions was in doubt.

Southern judges dealt with this problem by insisting that slaves, though property, were a particular kind of property possessing free will. There was, however, some slippage in judges' insistence on slaves' free will. For instance, judges realized that slaves were not always in a position to exercise their wills freely. In nineteenth-century American law, the freedom to enter into voluntary contracts with others was a linchpin of free will and legal subjectivity. It was partly for this reason that a slave hired out by his master to do risky work needed more legal protection than did a free man. Whereas a free man had voluntarily agreed to undertake a certain type of work under certain conditions for certain remuneration, a slave had usually not entered into any such agreement, and his disobedience would put him in physical peril. ${ }^{27}$

In some cases, southern judges were willing to move even further in doubting a slave's free will. Significantly, two of the

26. Mark V. Tushnet, The American Law of Slavery, 1810-1860 (Princeton, NJ, 1981), 53; Eugene Genovese, Roll, Jordan, Roll: The World the Slaves Made (New York, 1976), 25-31.

27. Tushnet, American Law of Slavery. 
cases in which judges went furthest in positing will-less slaves involved the consumption of alcohol. In two important slave cases, Harrison v. Berkeley (1847) and Skinner v. Hughes (1850), slaves had purchased alcohol from white men, became intoxicated, and died. In both cases, the courts required the men who had sold the alcohol to compensate the owners of the slaves for having caused the intoxication leading to death. Although these cases were decided under the common law, the judges claimed that since the drinkers were slaves, common law precedents needed to be altered. They argued that slaves would naturally drink alcohol if it were offered them; they lacked the power of will to abstain. In Skinner, for instance, the court held that "the death of the slave was a natural consequence of the act of the defendant in providing him with the means of intoxication, the death having ensued without the occurrence of any such extraordinary conjunction of circumstances as that the usual course of nature has been departed from. ${ }^{\prime 28}$ In a sense, the judges were claiming that offering a slave a drink was tantamount to restraining him and pouring it down his throat. Functionally, the slave's act of consuming alcohol was held not to be a willed act superceding the sale in the chain of causation but rather a "natural consequence" of the sale. Logically this makes little sense, since in theory the defect in a slave's will was simply that his master's could be imposed upon it, and there was no evidence in these cases that the masters had caused their slaves to drink. What was happening was that two cultural presuppositions-that slaves lacked free will and that drinkers lacked free will-had run together in the judges' minds, and that the legal consequences of the former were being transferred to the latter by a kind of contagion.

One could imagine that in the North and after the Civil War judges could have heaved a great sigh of relief at the elimination of the highly problematic status of the slave. Why, then, almost fifty years after the end of slavery, did an important 1910 treatise on the law of intoxicating liquors devote two full pages to considering the regulation of sales of alcohol to slaves? The au- 
thors themselves explained that the regulations "still have sufficient interest to warrant a short review of the cases. ${ }^{\prime 29}$ The precedents were still significant precisely because they still lived on in other areas of law, including the civil damage acts. Although there is no "smoking gun," it seems likely, given the rhetoric of the mid-nineteenth century and the similarity between the decisions in cases such as Skinner and Harrison and the civil damage acts, that in drafting and advocating the civil damage laws of the 1840s through 1860s, legislators in Iowa, Pennsylvania, Massachusetts, and Wisconsin looked to those decisions for inspiration. At the very least, the southern decisions assigning responsibility for slaves' drinking to liquor purveyors and the northern legislation doing the same for free men emerged from a common concern about drink, slavery, and autonomy. By the 1870 s, when the civil damage laws had spread to many states and when enforcement of them began in earnest, the language of slavery pervaded northern civil damage act testimony, briefs, and decisions.

Civil damage act plaintiffs, their attorneys, and on occasion judges either metaphorically described drinkers as "slaves" or directly claimed that they lacked autonomy. The judge in an early Illinois civil damage case, People v. Frederick Mapes (1873), instructed jurors to take evidence that a man exercised "Will Power" as proof that he was "not a slave to his appetite for intoxicating liquor." A lawyer in Iowa in 1880 described drunkards as "slaves to their appetites." Louise Faivre's lawyer argued, about twenty years later, that "habitual drunkards" such as Andrew Faivre were "slaves of the saloon keeper." Another case suggested that a man's drinking had "fettered his will." Even when they did not use the language of slavery, court officials often claimed that drinkers, at least habitual drinkers, lacked free will and moral responsibility. The judge in a Michigan case, Lafler v. Fisher (1899), for instance, instructed the jury that an intoxicated man's "usual will power is temporarily suspended." Similarly, a plaintiff's attorney in another case suggested that when saloonkeepers sold alcohol to a man until he was drunk, they made "the will theirs and not his." In a decision in another civil damage case, the Iowa Supreme Court

29. Woollen and Thornton, Intoxicating Liquors, 736 , Article 2 , $\$ 736$. 


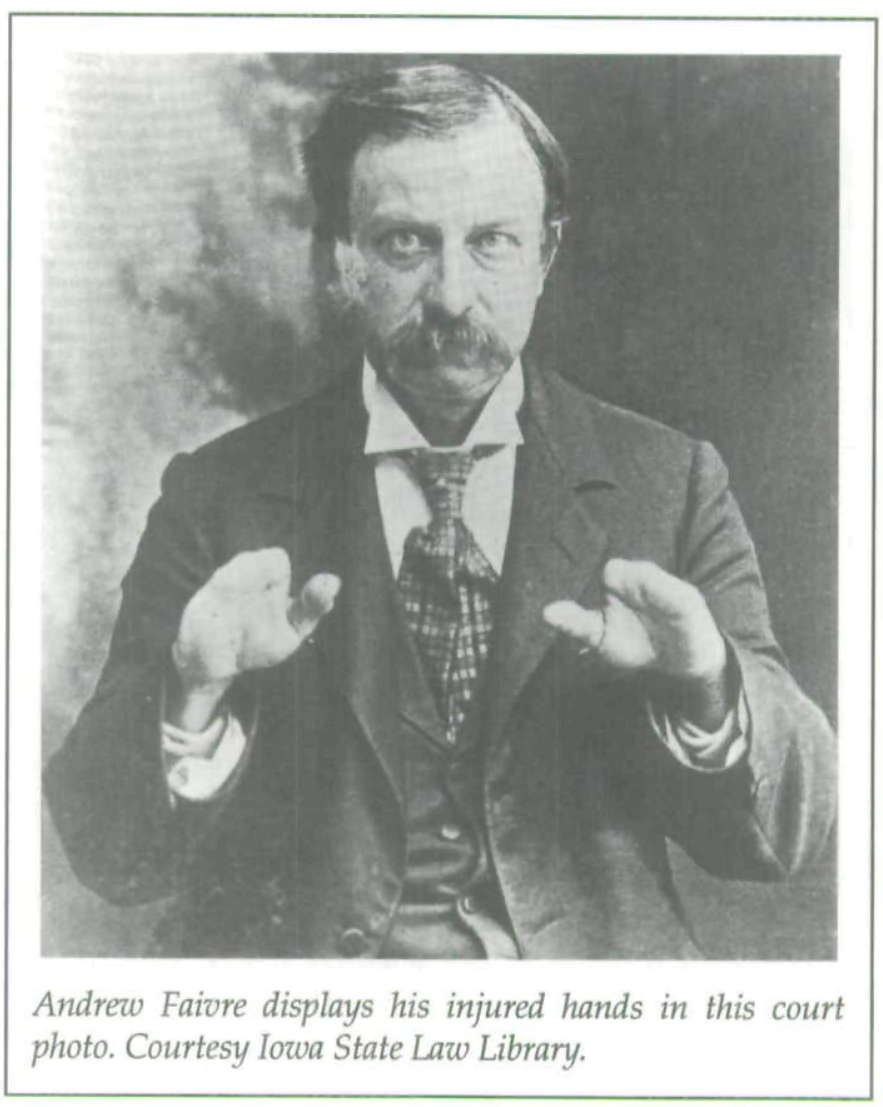

insisted that some drinkers' actions could not be seen as voluntary. Responding to the saloonkeeper's attorney's argument that "involuntary whiskey drinking is something foreign to human experience," the court insisted that "voluntary means spontaneously, of one's own will, without being moved, influenced, or impelled by others. It is one of the saddest facts in human nature that many persons do both buy and drink intoxicating liquor who, spontaneously, of their own will, without being influenced or impelled by others, would not have done so." ${ }^{30}$

30. State of Illinois v. Frederick Mapes (1873), p. 77, Case Files, Illinois State Archives (69 Ill. 523); J. E. Sansom v. James Greenough and Charles Bullock (1880), Appellee's Argument, p. 5, Bound Briefs, ISLL (55 Iowa 127, 7 N.W. 482); Louise Faivre v. John Mandersheid, John Arensdorf, and E. J. Ressegiu (1902), Appellee's Argument, p. 13, ibid. (117 Iowa 724, 90 N.W. 76); A. F. Bissell, Administrator of Estate of 
In all of these cases, legislators and courts were treating a class of white, male drinkers as though they were not autonomous and requiring saloonkeepers to answer for the consequences of those drinkers' actions. Some used even more degrading metaphors than slavery in connection with the civil damage acts. One saloon lawyer complained, "The underlying idea [of the civil damage act] is, that a drunken man is a sort of ferocious animal, and whoever puts him in that condition, must answer for his violence; the same as the owner of a vicious beast, who lets him loose to gore or injure others." A plaintiff's lawyer compared a drinker to "an infant of tender years, or an idiot, or a person NON COMPOS MENTIS from any cause." ${ }^{31}$

Drawing on the metaphorical language of temperance reformers, and on the recently abolished institution of slavery itself, courts in civil damage act cases began to work under the premise that at least some drinkers lacked free will. Courts increasingly adopted the metaphorical understanding of the drunkard as willless and took unprecedented steps to deal with him in the face of his lack of will. The arguments that moved juries and, one presumes, judges and legislators as well, to take this step depended to a large extent not on scientific or philosophical reasoning but on the power of the drunkard narrative, which had already minimized the existence of the drinker's will, and which was increasingly retold as a guide to public policy.

Plaintiffs' lawyers portrayed saloonkeepers as melodramatic villains, "chuckl[ing] ... with glee" while pocketing the money from desperate drinkers' wives' "toil at the washtub. ${ }^{132}$ Lawyers

Frank S. Law, Deceased v. Frank Starzinger (1900), Appellant's Argument, pp. 6 and 10 (quoting from [William Henry?] Schooler on Wills), ibid. (112 Iowa 266, 83 N.W. 1065); Martha Lafler v. Edward L. Fisher, Henry Kirchgessner, and Enos Plumadore (1899), Instructions to Jury, p. 127, Bound Briefs, Michigan State Law Library (121 Mich. 60, 79 N.W. 934); Carrie Kearney v. James Fitzgerald (1876), Appellant's Brief, pp. 37, 586, ibid. (43 Iowa 580). For a broader treatment of the history of ideas of alcohol's threat to the will, see Mariana Valverde, Diseases of the Will: Alcohol and the Dilemmas of Freedom (New York, 1998).

31. E. M. Calloway, Appellee v. James Laydon, Appellant (1877), Appellant's Argument, p. 10, Bound Briefs, ISLL (47 Iowa 456); Bissell v. Starzinger, p. 5 (emphasis in original).

32. Elizabeth Engleken v. Hubert Webber and John Weston (1877), Appellee's Argument, p. 4, Bound Briefs, ISLL (47 Iowa 558). 
painted grim pictures of saloonkeepers' deliberate attempts to oppress their patrons' families. Take, for instance, the flowery rhetoric used by the lawyer for Mary Judge in the passage that opens this article. In beginning his argument with a "brief summary of the humble lives of the plaintiff and her husband the two principal characters in this tragical case," going on to describe how "whiskey, the demon of man," deliberately wielded by a saloonkeeper, destroyed the "happy little home" of a "strong, able bodied, healthy, hard working, laboring man . . . honest and industrious" and his "darling wife... spotless in the crowning glory of woman," he was squeezing temperance melodrama for all it was worth. ${ }^{33}$

TEMPERANCE HISTORIAN Jack Blocker has argued that the civil damage acts did not do much to improve conditions for drinkers' families, since plaintiffs often lost on appeal and since they often had a difficult time collecting their money even when they won. ${ }^{34} \mathrm{He}$ certainly has a point: Iowa plaintiff Kate Buckham, for instance, succeeded in winning $\$ 3,000$, but had to bring an entirely new suit to get her money when the defendant transferred his property to another person to avoid paying her. ${ }^{35}$ But even if it did not always function as legislators may have hoped, the act had a major impact on the lives of drinkers, drinkers' dependents, and saloonkeepers alike.

Drinkers' wives were foremost in the minds of legislators when they passed civil damage laws. They intended to assist women whose husbands had been led astray and no longer supported them. In fact, even if these women had a difficult time claiming the money they had been awarded, the very existence of the laws gave them an important weapon to wield against their husbands' saloonkeepers. Mary Fox of Dubuque, for instance, testified that before bringing her case in 1881 she had approached her husband's saloonkeeper personally, saying, "I wish yourself and also notify [other saloonkeepers] not to sell

33. Judge v. Jordan, Appellee's Argument, p. 1.

34. Blocker, Give to the Winds thy Fears, 132.

35. Kate E. Buckham v. H. R. Grape and Elizabeth White (1885), Bound Briefs, ISLL (65 Iowa 333, 22 N.W. 664). 
or give my husband any intoxicating liquors. I said he neglects work and is also neglecting his family. ${ }^{\prime 36}$ Her claim that he did not adequately heed her warning was at the heart of her lawsuit. Saloonkeepers usually knew that they could not afford to dismiss family members' complaints. If wives could, by raising the specter of a civil damage suit, scare their husbands' saloonkeepers out of selling alcohol to them, they could, and did, also use that power as a bargaining chip with their husbands, threatening to have a word with saloonkeepers if husbands did not straighten out.

Saloonkeepers usually took wives' threats seriously because they did pose a very real problem for them. The families of drinkers, often impoverished and bereaved, evoked juries' sympathies more readily than saloonkeepers, and they frequently won in their initial trials. Even if saloonkeepers managed to win on appeal, in the meantime they had to invest significant time and money in the process. Furthermore, as businessmen dependent on the good will of their customers, they could ill afford to land in the middle of local controversy. Surely, the mere possibility of a civil damage suit caused saloonkeepers to think twice about whether their profit on another glass of whiskey was worth the risk.

SALOONKEEPERS AND DRINKERS were not without their defenders, however. Such defenders of moderate drinking resisted defining drinkers as slaves. Instead, they argued, "humans were innately possessed of self-government; to say otherwise was to destroy their will and place them in the grips of an outside power. ${ }^{\prime \prime 7}$ Temperance rhetoric's definition of drinkers as slaves, which suggested that they lacked their own wills, served as the chief rallying point for temperance opponents. They attacked reformers' understanding of drinkers' autonomy both by insisting that it was not true and by pragmatically arguing that

36. Mary Fox v. John Wunderlich (1884), Bound Briefs, ISLL (64 Iowa 187, 20 N.W. 7).

37. David S. Reynolds, "Black Cats and Delirium Tremens: Temperance and the American Renaissance," in David S. Reynolds and Debra J. Rosenthal, eds., The Serpent in the Cup: Temperance in American Literature (Amherst, MA, 1997), 31. 
adopting such an understanding would dangerously undermine the traditions of freedom at the core of America's heritage.

When temperance opponents challenged reformers' claims about free will, they often did so in religious language. They readily admitted, as it would have been difficult for them to deny, that some individuals drank to excess, and that their families and communities suffered for it. But they argued that excessive drinking was only one among many vices in which sinful men and women chose to indulge. It was true that it became progressively more difficult for frequent drinkers to stop drinking, but that was because indulging in any sin increases the sinner's desire to sin. In this case, temperance opponents agreed with Puritan divine Jonathan Edwards, who had argued more than a century earlier that the habitual drinker did not lose his ability to stop drinking; he did not become "addicted" or "enslaved" to drink. ${ }^{38}$ Instead, he repeatedly opted to sin because sinning became increasingly attractive to him.

Temperance opponents' view of excessive drinking as the product of a sinful rather than an impotent will often led them, unlike temperance reformers, to criticize the general character of excessive drinkers. "When a man disgraces himself in any other way," Kansas newspaperman Edgar Watson Howe claimed, "we insist that he must be humiliated, as sending him to jail for petty larceny, or to public work for vagrancy; but when he becomes a disgusting, beastly drunkard, we tell him in confidence that he is not to blame, and that his enemies the saloon-keepers, are responsible." ${ }^{139}$ Saloon defenders, like temperance reformers, emphasized that those who drank excessively often chose to practice other vices as well. But whereas reformers saw the other vices proceeding from the paralysis of the will caused by drink, saloon proponents believed that generally sinful men chose to drink to excess, just as they chose to indulge in other sorts of excess. They saw drunkenness as a consequence of, rather than a cause of, sin and vice. This is the larger intellectual context for saloonkeepers' lawyers' clearly pragmatic but strikingly critical

38. Jonathan Edwards, Freedom of the Will, ed. Paul Ramsey (New Haven, CT, 1957), 139, 143-44.

39. Edgar Watson Howe, The Story of a Country Town (Atchison, KS, 1883), 98. 
stance towards excessive drinkers in civil damage suits. "He's a shiftless, lazy, drinking sort of a creature?" asked one lawyer. Another described a subject of a suit as "one of this class of boys that are brought up in town that do not work." A third referred to excessive drinkers as "old bum[s]" and as "vicious." A fourth described a drinker as "accustomed also to gambling and practicing other evil vices, [who] was also a spendthrift and devoted his time to drinking, gambling, and idleness." Some judges instructed juries that if a drinker's actions were caused not by his drunkenness but by his "natural inclination or general depravity," plaintiffs could not recover. ${ }^{40}$

The anti-temperance insistence on the personal responsibility of the drinker for his actions was both religious and political. First, it emerged from a commitment to the idea of sin and a passionate rejection of the perfectionism it understood to be pervading the temperance movement. As one anti-temperance pamphleteer put it, "Prohibition was first tested in the Garden of Eden-and failed. The fall of man and his free agency were the results. All the imperfections of our moral nature are, according to the Scripture, consequences of this first failure of prohibition; for had not Eve plucked and eaten the forbidden fruit, man would be perfect. As it is, we are foredoomed to sin and suffer for sinning, but we are free agents. ${ }^{141}$ Like late twentiethcentury opponents of gun control who insist that "guns don't kill people: people kill people," prohibition opponents took issue with the idea that the availability of alcohol caused individuals to act immorally. One temperance opponent, writing to a temperance newspaper, complained that "much is said of Alcohol destroying such vast numbers of lives, as if it was the active agent in the matter. ${ }^{\prime \prime 2}$ Because temperance reforms were

40. Douglas D. Lowry v. Sylvia L. Coster (1877), testimony of John Hable, p. 49, Case Files, ISA (91 Ill. 182); George E. Jewell v. Patrick Welch, Herbert Babcock, and Andrew Haberstumpf (1898), p. 14, Bound Briefs, MSLL (117 Mich. 65, 75 N.W. 283; Bissell v. Starzinger, Appellee's Argument, p. 5; Jennie E. Woody v. John Coenan (1876), p. 4, Defendant's Response, ibid. (44 Iowa 19); Harriet Dennison v. Charles W. Van Wormer, Myer Ephraim, and Thomas Doyle (1895), Charge to the Jury, p. 35, Bound Briefs, MSLL (107 Mich. 461, 65 N.W. 274.

41. G[allus] Thomann, Real and Imaginary Effects of Intemperance: A Statistical Sketch (New York, 1884), 66.

42. Iowa Temperance Standard, 10 June 1869. 
based on a flawed perception of the nature of sin, opponents believed, they would fail. In the earlier decades of the century, one writer had evoked the "native depravity of the human heart" as the ineradicable root of drunkenness. Although much of this rhetoric was toned down in later decades, temperance opponents' insistence on human imperfection remained constant. $^{43}$

If temperance opponents were right, of course, neither a judgment against a saloonkeeper nor any larger prohibition agenda would be an appropriate way to help the drunkard and his family. Social progress, if it happened, would result not from limiting an individual's opportunity to sin, but from the individuals' own moral improvement. As an opponent of prohibition put it, "We believe it pleased God, in the creation of all things, to place before man good and evil, and to make him a free moral agent to choose between the two knowing, in His infinite wisdom, that in the fullness of time man would be led to choose the good alone, and so the evil would have wrought successfully for his discipline. ${ }^{\prime 44}$ This anonymous author was more sanguine about the possibilities of social improvement than were most opponents of prohibition, but the argument against "legal suasion" was typical.

Acting as though drinkers lacked responsibility for their actions, opponents of prohibition worried, would only encourage them to pursue viciousness, secure in the belief that they would be neither punished nor blamed. Walt Whitman made this common pro-drink argument in his highly idiosyncratic early temperance novel, Franklin Evans (1842). "I have sometimes thought," he wrote," that the laws ought not to punish those actions of evil which are committed when the senses are steeped in intoxication. But if such a principle were allowed to influence judicial decisions, how terrible an opening there would be! How great a temptation, even, to the let-

43. "A Clergyman" [Rev. C. Reed], Reasons for Not Joining the Temperance Society (Richmond, VA, 1836), 22.

44. New England Journalist, The Ramrod Broken; Or, The Bible, History, and Common Sense in Favor of the Moderate Use of Good Spirituous Liquors: Showing the Advantage of a License System in Preference to Prohibition, and "Moral" in Preference to "Legal Suasion" (Boston, MA, 1859), 22. 
ting loose of the worst passions. ${ }^{\prime 45}$ In lifting blame from drinkers' shoulders, reformers took away whatever incentive drinkers may have had to improve and perhaps encouraged them to even worse crimes.

But the greatest danger of the path temperance reformers were pursuing, their opponents argued, was that in falsely imagining that a class of people lacked free will, they threatened actually to rob them of the freedom to exercise that will. William Novak traces this line of argument among opponents of prohibition and argues that, in fact, opponents of prohibition were absolutely correct in perceiving prohibition legislation as having "transformed traditional understandings of the scope of legislation, the nature of rights, and the locus of public power" in such a way as to limit traditional freedoms. ${ }^{46}$ The freedom to choose sin, they argued, was an essential aspect of moral liberty. As an antebellum southern pamphleteer insisted in 1836, "as a moral agent, [man] is endowed with both reason and appetite. ... through fear of his ruin, shall we impose on him restraints in advance? Then suppress all his appetites.... reduce him at once to a mere stock and stone; he then will be safe. ${ }^{\prime 47}$ Only by depriving man of freedom, enslaving, or even dehumanizing him, could society ensure that he would not choose sin.

Temperance opponents also believed that, in letting the drunkard off the hook for his behavior, temperance reformers threatened to erode the basis of American political liberty. Much to the discomfort of temperance reformers, organizations of saloonkeepers and their supporters frequently invoked the language of freedom and liberty. Temperance opponents tended to give their organizations names such as "Personal Liberty League" and give speeches such as "Prohibition versus Personal Liberty" invoking hereditary rights. ${ }^{48}$ Saloon supporters

45. Walt Whitman, Franklin Evans; Or, The Inebriate (New York, 1929), 147.

46. William J. Novak, The People's Welfare: Law and Regulation in NineteenthCentury America (Chapel Hill, NC, 1996), 175.

47. "A Clergyman," Reasons for Not Joining the Temperance Society, 27.

48. B. H. Carroll, Personal Liberty: A Lecture by Rev. B. H. Carroll, D. D., delivered at Waco, Texas, January 18th, 1887 (Waco, TX, 1887); Almer M. Collins, Prohibition v. Personal Liberty; Or, The Liquor Traffic Critically Examined in the Light of Science, Theology, and Civil Government (St. Louis, 1882). Herbert Asbury, The 
used the language of liberty; in particular they emphasized its ties to the core of the nation's political heritage. As historians of drink and temperance in the United States have noted, the temperance movement, through the nineteenth century, had been gradually appropriating the term liberty to mean not "freedom from governmental interference" but rather "freedom from enslavement to alcohol. ${ }^{\prime \prime 9}$ The obligation to take responsibility for one's own actions was a prerequisite not only to morality but also to political liberty. If the choice to drink was not an autonomous choice of a free citizen, government could take away that choice without violating democratic rights and freedoms. If drinkers were more like slaves than like free men, temperance reformers insisted, prohibition violated no one's liberties.

By the end of the nineteenth century, supporters and opponents of the saloon, in Iowa and around the country, saw the relationship between government, the individual will, and drink very differently than they had at the beginning of the century. Temperance reformers had become irrevocably committed to the move the Iowa legislature had made during the Civil War. Most northern states had passed their own civil damage laws by century's end. Decades after slavery's end, temperance reformers still frequently mobilized the language of slavery in describing the drunkard's plight. In courtrooms and in countless stories, speeches, novels, poems, and plays, they repeated again and again that alcohol and its purveyors enslaved the will of male citizens, and that the government needed to step in forcefully to restore the proper order of things. Saloon defenders, who championed a more traditional, religiously inspired individualism, tended more and more to lose out in the public debate. Only with the perceived failure of prohibition during the Great Depression did their arguments begin to take on greater resonance once again.

Great Illusion: An Informal History of Prohibition (New York, 1950), 106, describes the founding of the Milwaukee Personal Liberty League in 1882. Duis, The Saloon, 81, discusses the founding of Chicago's Liberty League in 1875.

49. W. J. Rorabaugh, The Alcoholic Republic: An American Tradition (New York, 1979), 37. 
THE HISTORY of Smith's Civil Damage Liquor Law is worth remembering for two reasons. First, it sheds light on the emergence of an idea of legal responsibility that is still very much with us, and still very controversial, today: the idea that the purveyor of an addictive substance can be held accountable for the actions of his or her customer. As long as we continue to consider the concept of unalienable individual responsibility as one of the keys of our social order, and as long as we continue to sense that there are many forces in society that individuals cannot resist effectively, this tension will continue to be a social issue. Just as importantly, however, the history of Smith's Civil Damage Liquor Law reminds us of how fluid ideas can be. Prejudices and fears about African Americans and, to a lesser extent, about American Indians, affected how a large group of nineteenthcentury white men came to be treated under the law. The metaphor of slavery was an enormously powerful one in the nineteenth century, and it had serious practical consequences, as "slaves to the bottle" and their defenders came to understand all too well. 
Copyright of Annals of Iowa is the property of State of Iowa, by \& through the State Historical Society of Iowa and its content may not be copied or emailed to multiple sites or posted to a listserv without the copyright holder's express written permission. However, users may print, download, or email articles for individual use. 